\title{
An uphill battle? The elevational distribution of alien plant species along rivers and roads in the Austrian Alps
}

\author{
Tom Vorstenbosch ${ }^{1,2}$, Franz Essl', Bernd Lenzner ${ }^{1}$ \\ I Bioinvasions, Global Change, Macroecology-Group, Department of Botany and Biodiversity Research, Divi- \\ sion of Conservation, Vegetation and Landscape Ecology, University Vienna, Rennweg 14, 1030 Vienna, Austria \\ 2 Institute of Biology Leiden, Leiden University, Sylviusweg 72, 2333 BE, Leiden, Netherlands
}

Corresponding author: Bernd Lenzner (bernd.lenzner@univie.ac.at)

Academic editor: I. Kühn | Received 4 June 2020 | Accepted 17 September 2020 | Published 22 October 2020

Citation: Vorstenbosch T, Essl F, Lenzner B (2020) An uphill battle? The elevational distribution of alien plant species along rivers and roads in the Austrian Alps. NeoBiota 63: 1-24. https://doi.org/10.3897/neobiota.63.55096

\begin{abstract}
Ever-increasing international trade and anthropogenic activity has led to the relocation of thousands of plant species worldwide. So far, the harsh climate of the European Alps historically has restricted the establishment of alien plants. However, new opportunities created by rising temperatures and increasing human activity might allow alien plants to spread further upwards. Here, the distribution of alien plants along an altitudinal gradient in two Austrian valleys is analyzed. Specifically, the distribution along two contrasting corridors (roads, rivers) and the spread of alien plants into adjacent habitats is examined. Following the MIREN sampling protocol, 20 transects composed of three plots along each river and main road, were established in each study region. Plant species cover and a range of site-specific factors were collected. In total, 641 plant species were recorded, of which 20 were alien. Alien species richness along roads was slightly higher compared to rivers, and the composition of the alien flora differed markedly between roads and rivers. Further, alien plant species richness decreases with distance to roads and rivers (indicating that adjacent habitats are less invaded), as well as with increasing elevation. Mowing along roadsides resulted in lower alien plant species cover, but higher alien plant species richness. Finally, compositional dissimilarity between sites showed that elevation, proximity of a plot to a river or road, and alien plant cover are important factors for higher dissimilarity. This study demonstrates that both natural (rivers) and manmade (roads) corridors play an essential role in the upward spread of different alien plants in mountains.
\end{abstract}

\section{Keywords}

community composition, conservation, corridors, elevation, mountains, mowing, networks, spread 


\section{Introduction}

Rising intensity of international trade and anthropogenic activity increases the humanmediated transport of plant species to regions beyond their native range. The introduction of alien plant species accelerated over the past centuries with the expansion of the global trade network (Hulme 2009; Seebens et al. 2015, 2017; Amano et al. 2016; Kueffer 2017; van Kleunen et al. 2018). Many plants that are transported by anthropogenic means face difficulties in reproducing and finally establishing themselves successfully in their new location due to climatic or other environmental constraints (Caley et al. 2007; Stotz et al. 2016). Nevertheless, globally at least 13,168 alien plant species managed to establish (i.e. form viable populations) in their new environments (van Kleunen et al. 2015), and there is no sign of a saturation of alien plant species accumulation (Seebens et al. 2017).

Mountains are generally subject to lower levels of plant invasion in comparison to lowland areas, and invasions into high elevations are rare (Lembrechts et al. 2016a; Haider et al. 2018). However, there is strong evidence that mountain systems are becoming more susceptible to plant invasions (Pauchard et al. 2009; Kueffer et al. 2013; Pauchard et al. 2016) particularly due to climate change (Walther et al. 2009; Bellard et al. 2018). Increasing temperatures may translate into greater habitat availability for alien species (Lenoir et al. 2008; Petitpierre et al. 2015; Carboni et al. 2018). At the same time, climate change alters the distribution of native biota (Alexander et al. 2018), thereby making mountains more vulnerable to invasions (Diez et al. 2012). For instance, it has been shown that several alien plant species in the Swiss Alps are occurring at higher elevations compared to a few decades ago (Becker et al. 2005). In addition, many newly introduced alien species undergo a 'lag phase', i.e. range expansion, that often follows with substantial delay after initial introduction (Aikio et al. 2010; Rouget et al. 2016; Alexander et al. 2018). This implies that many alien species are still expanding, and that the equilibrium distribution of alien plant species will be considerably larger than their current one.

Corridors connecting different habitats (e.g. rivers, roads) play a decisive role in the spread of alien plants (Pattison et al. 2017; Rauschert et al. 2017; Follak et al. 2018). So far, studies in mountains have mainly focused on road networks as facilitators for the dispersal of alien plant species (Alexander et al. 2016). Vehicular traffic plays a critical role in the rapid dispersal of seeds (von der Lippe and Kowarik 2007; Lemke et al. 2019). Frequent disturbances along roadsides create opportunities for the establishment of alien species (Hansen and Clevenger 2005), and these roadside habitats allow the spread of alien plants into higher elevations (Alexander et al. 2016; Lembrechts et al. 2016a; Seipel et al. 2016). From there, species might subsequently spread into adjacent less-disturbed habitats (McDougall et al. 2018). However, while it is well-understood that European riverine habitats show high levels of plant invasion (Hejda et al. 2009; Kalusová et al. 2013), comparatively less work has been done on studying the role of rivers rather than of roads for the spread of alien plants in mountains (but see Siniscalco et al. 2011 and Barni et al. 2012). 
Riverbanks typically harbor many native plant species of conservation interest. These experience increased competition with the arrival of alien plant species in these habitats (Naiman and Décamps 1997). Studies in lowland areas have shown that the constant movement of rivers provides opportunities for rapid seed dispersal of alien plant species into previously uninvaded areas (Pyšek and Prach 1994; Aronson et al. 2017). River corridors do not solely facilitate the spread of alien plants downstream but have also been observed to do so upstream (Wang et al. 2011; Osawa et al. 2013). Changes in riverside vegetation by alien plants can lead to erosion and may ultimately disturb ecosystem services (Richardson et al. 2007; Greenwood et al. 2018).

In the face of increasing numbers of alien species, a series of control programs have been enacted in Austria to prevent the establishment, hinder further spread, or to eradicate (invasive) alien species (Schiffleithner and Essl 2016). One of these methods is mowing, which is a common practice at roadsides of the European Alps for both conservation efforts and road safety (ASFINAG 2019). However, mowing can have diverging effects on alien and native plants depending on the individual species and the timing of the mowing event, indicating that this method should be considered on a case-by-case basis (Vitalos and Karrer 2009; Kettenring and Adams 2011; Song et al. 2018).

The aim of this research was to analyze and compare the role of natural (rivers) and man-made (roads) corridors for the spread of alien plant species in mountain valleys. Specifically, the following research questions were addressed:

1) What is the elevational distribution of alien plant species along rivers and roads?

2) What is the effect of roadside mowing on the distribution of alien plant species richness and cover?

3) Do plant communities along rivers and roads, and with different proximities to these corridors, show a dissimilarity in composition?

4) Which factors, including the occurrence of alien plant species, affect plant community composition?

\section{Methods}

\section{Study regions}

Climate. In Austria, where $60 \%$ of the country has an elevation above $500 \mathrm{~m}$, alien species are mostly confined to the lowlands and large river valleys in the Alps (Walter et al. 2005). For this study, we selected the main rivers and roads of two mid-size Austrian valleys as study regions: the Lech valley located in the Northern Alps, and the Isel valley located in the Central Alps (Fig. 1A, B, D). Both study regions represent rural, somewhat agricultural, landscapes dominated by forests, mountain pastures and grasslands, while the major rivers are still highly dynamic and in near-natural condition. The Lech valley has a predominantly oceanic climate and calcareous bedrock. The 
A

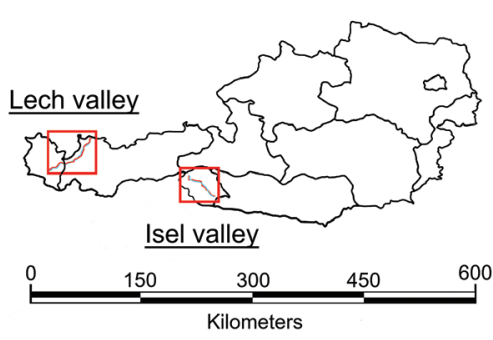

C

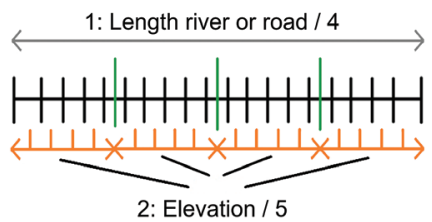

B

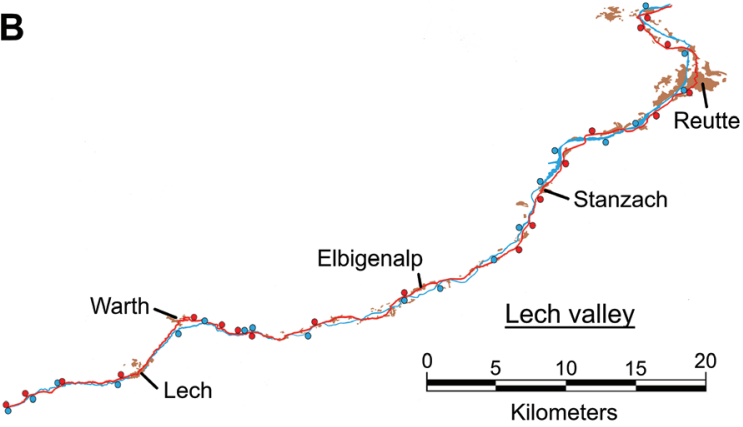

D

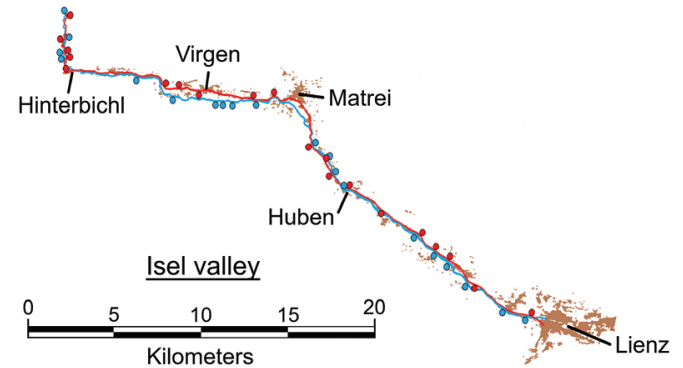

Figure I. Locations of the study regions and distribution of transects along both rivers and roads. A the Lech valley makes up part of the federal states Tyrol and Vorarlberg. The Isel valley is located in the eastern part of Tyrol ("Osttirol") B topographical map of the river (blue) and road (red) with larger towns and built-up areas (brown) in the Lech valley. Points indicate the positions of transect $\mathbf{C}$ illustrated here is the method applied to distribute 20 transects along each river and road. First, the total length of each river and road was divided into four equal sections (green). Secondly, the elevational range of each section was divided into five equal-elevation parts (orange). The center of each part subsequently determined the position of each transect (black), with the exemption of the lowest and highest transects that were placed on the end points of each river and road $\mathbf{D}$ same as in panel B but for the Isel valley.

mean annual temperature is $7.3^{\circ} \mathrm{C}$ and it has a mean annual precipitation of $1397 \mathrm{~mm}$, near the town of Reutte at $842 \mathrm{~m}$ a.s.l. Further up-valley in Warth at $1478 \mathrm{~m}$ a.s.l., the mean annual temperature drops to $4.7^{\circ} \mathrm{C}$, with a mean annual precipitation of 1867 $\mathrm{mm}$ (ZAMG 2019). The Isel valley is dominated by siliceous bedrock. This valley sees a mean annual temperature of $8.5^{\circ} \mathrm{C}$ and a mean annual precipitation of $944 \mathrm{~mm}$, at an elevation of $661 \mathrm{~m}$ a.s.l. In the village of Virgen at $1212 \mathrm{~m}$ a.s.l., the mean annual temperature is $6.7^{\circ} \mathrm{C}$, with a mean annual precipitation of $850 \mathrm{~mm}$ (ZAMG 2019).

Topography. The Lech river originates to the southwest of the village Lech at 1840 $\mathrm{m}$ a.s.l. and runs northeast, stretching $256 \mathrm{~km}$ in total before it flows into the Danube. The Austrian-German border ( $824 \mathrm{~m}$ a.s.l.) marks the lowest point included in this study, and the distance between this point and the source is approximately $90 \mathrm{~km}$. The end of the riverbed marks the highest point included (1816 $\mathrm{m}$ a.s.l). The Lech river is characterized by the way it alternately flows through gorges and sections of broad river valleys with a braided riverbed (Müller and Bürger 1990). The main road mostly runs along the river at the bottom of the valley but ascends to slopes along the gorges. 
The Isel river and its accompanying road have a length of approximately $57 \mathrm{~km}$. Its main source is the Umbalkees glacier (2400 m a.s.l.) in the Hohe Tauern mountains. The Isel river flows into the Drau river near the city of Lienz (673 $\mathrm{m}$ a.s.l.). This point therefore marked the lowest elevation in the study. As high alpine elevations are unlikely to contain alien plant species (Becker et al. 2005; Pauchard et al. 2009; Alexander et al. 2016), the upmost transect was established near the Johannis mountain hut at $2121 \mathrm{~m}$ a.s.l. The rise in elevation along the course of the river is roughly exponential as is characteristic for glacier valleys (Montgomery 2002).

\section{Sampling design}

Transect layout. The study design along rivers and roads followed a similar approach to ensure that results were comparable. The underlying method was structured following the method designed by the Mountain Invasion Research Network (MIREN) (Seipel et al. 2012). Each transect had a T-shape and consisted of three plots, all sized $50 \mathrm{~m} \times 2 \mathrm{~m}$. The first plot (river/road plot) was placed parallel to the road or river. The second plot (intermediate plot) was positioned at a $90^{\circ}$ angle adjacent to the center of the river/road plot. The third plot (interior plot) was set up next to the intermediate plot in the same orientation (Fig 2). Roadside plots were placed next to the unvegetated edge on the road verge. The road verge, in contrast to the road edge, was vegetated but showed signs of mechanically induced disturbance (e.g. road construction/ maintenance, overrunning). In practice, the road edge did not exceed a few $\mathrm{cm}$ in the Isel valley and not more than $60 \mathrm{~cm}$ in the Lech valley, while the road verge was up to $101 \mathrm{~cm}$ wide in the Isel valley and up to $158 \mathrm{~cm}$ wide in the Lech valley.

Mowing protocols along roadsides were designed and executed by the ASFINAG, the Austrian publicly-owned corporation responsible for road maintenance. A total of 14 transect locations along roads in the Isel valley and 15 in the Lech valley were subject to mowing. The use of similar mowing machines in both areas led to comparable and systematic mowing regimes (ASFINAG 2019). In all cases, it was clearly visible up to where the vegetation was mown ('mowing line', see picture in Suppl. material 2: Appendix 1). We placed the fourth plot (mowing line plot) next to the mowing line in the first strip of unmown vegetation, parallel to the road plot (Fig. 2B). On average, the distance between the road edge and the mowing line was $451 \mathrm{~cm}$ in the Isel valley, and $495 \mathrm{~cm}$ in the Lech valley.

Transect positioning. Transects locations were established using ArcGIS 10.2.2 (ESRI 2014), by dividing the total length of both the rivers and roads into four equal sections. These four sections were subsequently divided into five equal-elevation parts, each covering the same elevational range. Transects were placed in the center of each of the resulting 20 elevational bands, except for the first and last transect of each road and river that were placed at the lowest and highest points of the study region (Fig. 1C). The side of the river or road at which the transect was established was chosen at random using a binary random number generator, unless one side was inaccessible (e.g. 
A

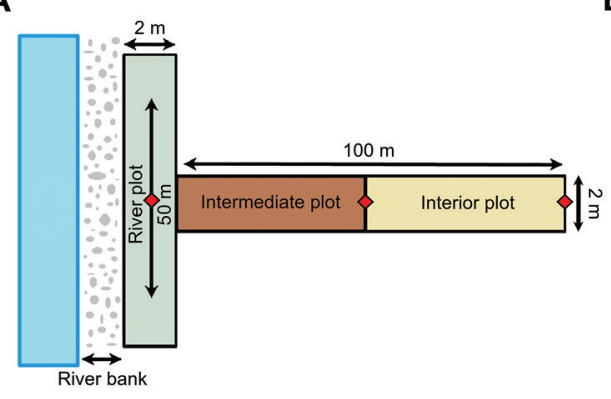

B

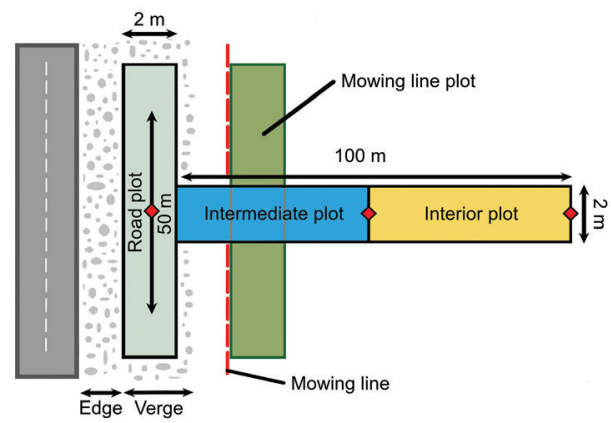

Figure 2. Study design illustrating the layout of the river $(\mathbf{A})$ and road (B) transects. All plots had a size of $50 \mathrm{~m} \times 2 \mathrm{~m}$. The measurement points for the coordinates of each plot are visualized by a red rhombus. A the river plot was positioned at the line where $50 \%$ of the surface of the riverbank was covered by herbaceous species. The riverbank width was the area which was covered in gravel and had very little or no vegetation $\mathbf{B}$ the road plot was positioned adjacent to the non-vegetated road edge at the road verge. The road verge was characterized by the first occurrence of vegetation. To quantify the effect of mowing, a plot was established directly beyond the mowing line (i.e. in the first unmown vegetation). The mowing line plot followed the same orientation as the road plot.

due to steep cliffs). Transects were relocated when the river or road was surrounded by agricultural land or built-up areas. Transects were preferably placed at least $100 \mathrm{~m}$ away from secondary roads or streams. If these requirements were not met, the transect was moved to the closest location where they were fulfilled.

Plot coordinates were recorded in the field with a Garmin eTrex 10 GPS device and verified in ArcGIS. Elevation and location for river and road plots were measured in their center. For intermediate and interior plots, this was recorded at the end of the plot most distant from the river or road (Fig. 2). From these values, the average elevation of the intermediate and interior plots was subsequently calculated for the statistical analysis. The width of the river, riverbank, road, road verge and road edge were measured in meters by taking the average of six measurements at every $10 \mathrm{~m}$ mark of the river/road plots. ArcGIS was used to check or perform the measurement of the river and road width, in case in-field measuring proved to be infeasible (see Suppl. material 1 for all plot information, including environmental data).

\section{Species data collection}

The cover of all vascular plant species was recorded in every plot. Plants were determined at species level. Taxonomy and nomenclature followed Fischer et al. (2008). Species occurrences were grouped by height and life form into the: (1) herb layer (herbaceous species of any height and woody species with or lower than $30 \mathrm{~cm}$ in height); (2) shrub layer (woody species between 30 and $300 \mathrm{~cm}$ in height); and (3) tree layer (woody species 
with or taller than $300 \mathrm{~cm}$ in height). Species were categorized as native (including archeophytes, i.e. plant species introduced before 1492) and alien (= neophytes), i.e. plant species introduced after 1492 (Essl and Rabitsch 2002). For each species, cover values (in \%) were estimated visually (Suppl. material 2: Appendix 2). The ratio of woody species to herbaceous species was subsequently calculated by subtracting the cover of the herb layer from the relative cover of trees together with that of shrubs.

\section{Data analysis}

Four separate analyses were conducted to evaluate alien species distribution and community composition at the plot level. We briefly introduce the different modelling approaches and expand on the details in the subsequent sections for the respective analyses. Bayesian modeling was used to analyze 1) patterns in alien species richness in relation to elevation and proximity to rivers and roads, and 2) the effect of mowing on both alien species richness and cover. Non-metric dimensional scaling (NMDS) was applied to 3) visualize dissimilarities in plot composition among corresponding plots and those from contrasting groups (i.e. corridor type, plot type). Lastly, permutational multivariate analysis of variance (PERMANOVA) was used to 4) examine whether the presence of alien species, among other factors, is associated with a change in plot composition. All analyses were performed with the software R, version 3.6.1 (R Development Core Team 2019).

\section{Alien species distribution}

The probability of alien species occurrence in each plot type in relationship to elevation was estimated through Bayesian inference implemented in the 'brms' $R$ package (Bürkner 2020). Given the high number of plots with zero alien plant species $(72 \%)$ we used a zero-inflated Poisson model (ZIP; Lambert 2012; Bürkner 2018). The ZIP model included elevation and plot type (road/river, intermediate, and interior) as explanatory variables, and alien species richness as response variable. To account for spatial autocorrelation, we included a nested random effect with the corridor (i.e. river or road) nested in the region (i.e. Isel or Lech). Bayesian approaches are able to account for a low number of groups $(<5)$ and low numbers of observations per group, respectively four and sixty in this study (Harrison et al. 2018).

Weakly informative priors were set for the random and fixed effects. A student-t distribution with ten degrees of freedom, a mean of zero and a standard error of three was incorporated as the prior for the explanatory variables. For the grouping ('random') variables, a half-Cauchy distribution with a shape parameter of one was specified. To control for over-dispersion and unbalanced grouping of zeroes at higher elevations, a smoothing spline with five dimensions was fitted for elevation (Opitz et al. 2013). 
To assess model convergence, each model ran four times with 5000 iterations (burn-in 2500 iterations), after which chain convergence was assessed visually (Suppl. material 2: Appendix 3). Post-run diagnostics were performed to determine whether the posterior predictions reflect the observed zero-inflation, maximum value, and the mean well. Additionally, the amount of autocorrelation was visually examined to determine the robustness of the model.

Mowing. Bayesian inference was used to assess the effect of mowing on alien species cover (\%) and alien species richness. A zero-inflated beta (ZINB) model and zeroinflated Poisson (ZIP) model were applied, respectively (Ospina and Ferrari 2012; Bürkner 2018). The mowing line plot and road plot were compared for all transects subject to mowing (Fig. 2B). Again, ZINB/ZIP models with the same weakly informative priors were used. As grouping variable we specified transect.

Model convergence was evaluated by running each model four times with 5000 iterations (burn-in 2500 iterations) and a consecutive visual assessment of chain convergence (Suppl. material 2: Appendices 4, 5). The zero inflation, maximum value, and mean of the posterior predictions were compared to their observed values to determine their fit. Finally, the model was checked visually for excessive autocorrelation.

Community composition analysis. Community dissimilarity across plots was assessed via Bray-Curtis dissimilarity using non-metric multidimensional scaling (NMDS) with Wisconsin double standardization and square root transformation via the metaMDS function from R package 'vegan' (Oksanen et al. 2019). The optimal number of dimensions for the NMDS-model was selected according to its corresponding stress value using the function dimcheckMDS of the R package 'goeveg' (Goral and Schellenberg 2018). The plot type (river/road, intermediate, interior) and corridor type (river, road) were used as grouping factors and for each region a separate NMDS-model was run. Alien species were included in the analysis, thus making up part of the plot community composition.

\section{Effect of alien species on plot composition}

A permutational multivariate analysis of variance (PERMANOVA) was performed with the adonis function of the $\mathrm{R}$ package 'vegan' to test whether elevation, plot type, woody-to-herbaceous species ratio, and alien species cover are related to a difference in plot composition (Anderson 2008). Alien plant species were included in the dissimilarity matrices. A total of 9999 permutations were run for each test.

The corridor was treated as a stratifying term, thereby limiting the permutations to specific roads and rivers. The betadisper function of the R package 'vegan' based on 9999 permutations allowed to check for homogeneity of dispersions across the different plot types and between rivers and roads. A pairwise comparison of the levels of plot type and corridor type was made using the pairwise.adonis 2 function of the $\mathrm{R}$ package 'pairwiseAdonis' (Arbizu 2019), with post-hoc Holm-Bonferroni adjustment of $p$-values (Holm 1979). 


\section{Results}

\section{Alien and native plant species richness and composition}

In total, 641 plant species were recorded in the study plots, of which $20(=3.1 \%)$ were alien plant species (Table 1). The total number of species $(n=500)$ in the Lech valley was almost identical to that of the Isel valley $(n=499)$. The number of species per plot in the Lech valley was significantly higher than the number of species per plot in the Isel valley $(t(358)=-5.69, p<0.001)$. Plant species numbers along roads $(n=511)$ were slightly higher than along rivers $(\mathrm{n}=499)$. The road in the Isel region had the largest alien species richness $(n=15)$, followed by the Isel river $(n=10)$, the road in the Lech region $(n=5)$, and the Lech river $(n=4)$.

The most common alien species found along rivers were Solidago canadensis, Impatiens parviflora, and Impatiens glandulifera. Along roads, the most common alien species were Matricaria discoidea, Erigeron canadensis, and Solidago canadensis. In general, the upper distribution limits of alien plants were lower along rivers $(833 \mathrm{~m})$ than along roads $(985 \mathrm{~m})$.

Table I. Alien plant species recorded in the study sites. Given are the species names of all species introduced after 1942 (= neophytes), its family, the observed elevational range (lower - upper limit in m a.s.l.) in which it occurs, the total frequency of occurrence in all plots, and the occurrence for each river and road in both regions.

\begin{tabular}{|c|c|c|c|c|c|c|c|}
\hline Species name & Family & $\begin{array}{l}\text { Elevational } \\
\text { range }(\mathbf{m})\end{array}$ & $\begin{array}{c}\text { Number of } \\
\text { plots }\end{array}$ & Isel river & $\begin{array}{l}\text { Lech } \\
\text { river }\end{array}$ & Isel road & $\begin{array}{l}\text { Lech } \\
\text { road }\end{array}$ \\
\hline Solidago canadensis & Asteraceae & $680-943$ & 26 & 13 & & 11 & 2 \\
\hline Impatiens parviflora & Balsaminaceae & $683.5-967$ & 19 & 10 & 2 & 7 & \\
\hline Matricaria discoidea & Asteraceae & $701-1323$ & 17 & & & 6 & 11 \\
\hline Erigeron canadensis & Asteraceae & $682-1265$ & 15 & 1 & & 14 & \\
\hline Impatiens glandulifera & Balsaminaceae & $683.5-953.5$ & 12 & 2 & 4 & 6 & \\
\hline Erigeron annuus & Asteraceae & $700-940$ & 11 & 2 & & 9 & \\
\hline Galinsoga ciliata & Asteraceae & $701-1323$ & 9 & & & 4 & 5 \\
\hline Cornus sericea & Cornaceae & $847-912$ & 4 & 1 & 2 & & 1 \\
\hline Fallopia japonica & Polygonaceae & $683.5-803$ & 3 & 2 & 1 & & \\
\hline Robinia pseudoacacia & Fabaceae & $1165-1205$ & 3 & & & 3 & \\
\hline Aesculus hippocastanum & Sapindaceae & 717 & 2 & & & 2 & \\
\hline Cotoneaster horizontalis & Rosaceae & $737-855$ & 2 & 1 & & & 1 \\
\hline Symphoricarpos albus & Caprifoliaceae & $1192-1205$ & 2 & & & 2 & \\
\hline Galinsoga parviflora & Asteraceae & 738 & 1 & & & 1 & \\
\hline Geranium sibericum & Geraniaceae & 682 & 1 & & & 1 & \\
\hline Medicago sativa & Fabaceae & 723 & 1 & & & 1 & \\
\hline Oxalis stricta & Oxalidaceae & $722-722.5$ & 1 & & & 1 & \\
\hline Parthenocissus inserta & Vitaceae & 683.5 & 1 & 1 & & & \\
\hline Silene dichotoma & Caryophyllaceae & $682-686$ & 1 & & & 1 & \\
\hline Solidago gigantea & Asteraceae & 803 & 1 & 1 & & & \\
\hline
\end{tabular}




\section{The effect of elevation and plot type on alien species distribution}

Alien species richness declined with increasing elevation and with distance from the corridor (Fig. 3, Table 2). Furthermore, alien species richness was higher in the Isel region (intercept $=1.14$ ) compared to the Lech region (intercept $=0.84$ ), as well as along roads (intercept Isel $=1.49$; intercept Lech $=1.01$ ) compared to rivers (intercept Isel $=$ 0.83; intercept Lech = 0.74; Suppl. material 2: Appendix 6, Fig. 4).
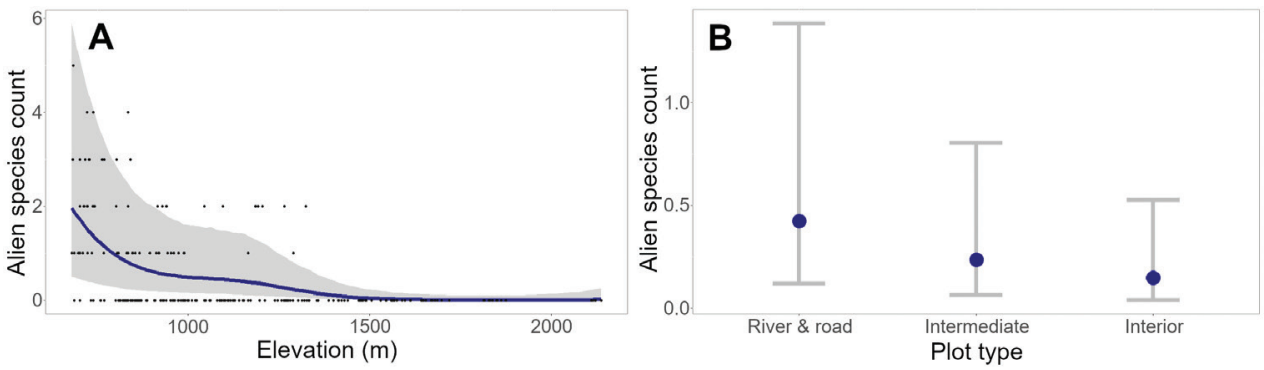

Figure 3. Posterior predictions of the ZIP model. Predicted richness of alien plant species across elevational gradients $(\mathbf{A})$ and plot types $(\mathbf{B})$ based on the zero-inflated Poisson (ZIP) regression model. Predictions are conditioned on all other predictors in the model.

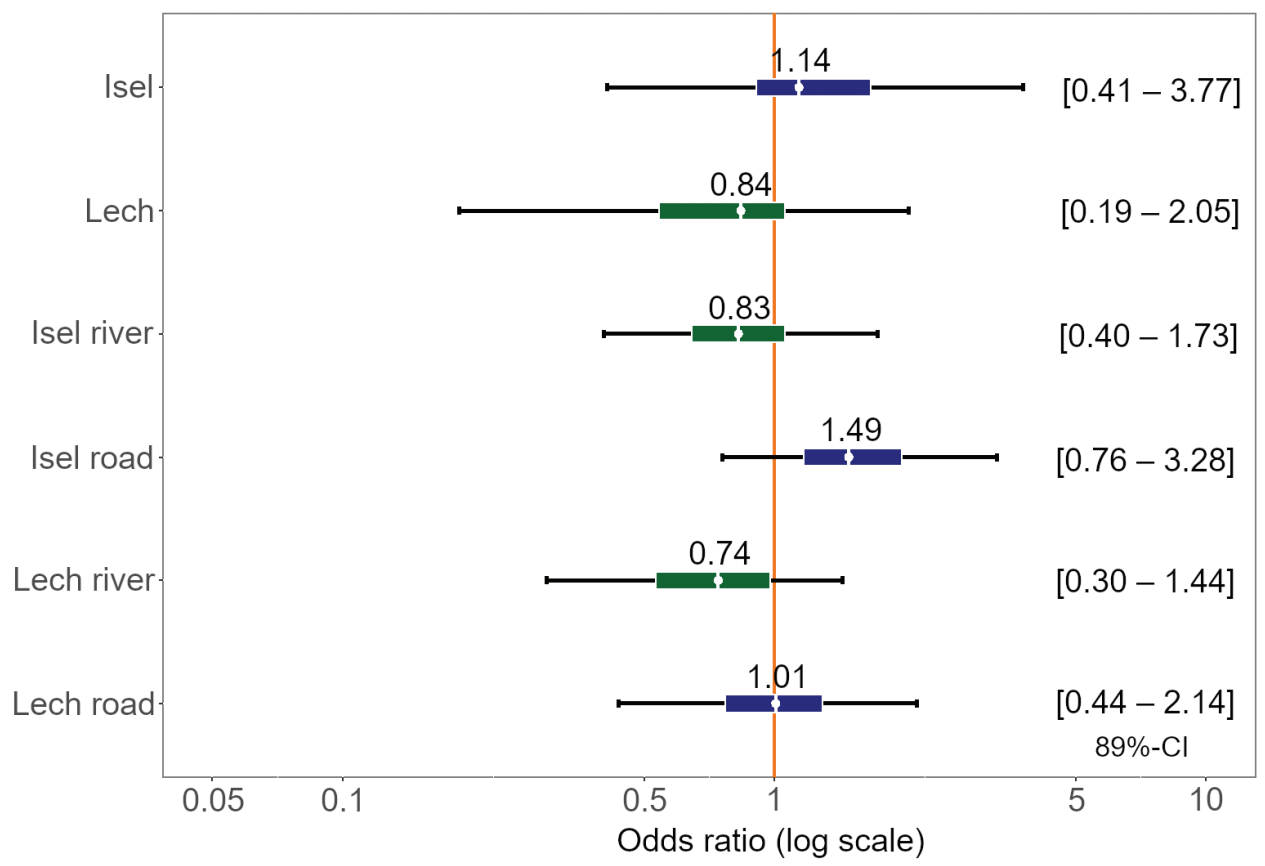

Figure 4. Estimated odds ratios of the random effects. The $50 \%$ and $89 \%$ credible interval of the factor region combined with the separate roads and rivers are shown. Odds are projected on a log scale. 


\section{The effect of mowing on alien species occurrence}

Mowing along roadsides significantly reduced alien species cover (coef $=-1.08,95 \%$ $\mathrm{CI}=[-1.93--0.16])($ Suppl. material 2: Appendix 7) but increased alien species richness (coef $=0.67,95 \%-\mathrm{CI}=-0.04-1.31$ ) (Suppl. material 2: Appendix 8). The zeroinflation probability of the cover model is notably higher $(0.48)$ than that of the species richness model (0.20) (Fig. 5).

\section{Compositional dissimilarity}

The NMDS for plot type in the Isel region shows a partial separation of river/road plots from the other two plot types (Fig. 6A) and no clear distinction between intermediate and interior plots. The floristic composition of plots along roads and rivers (Fig. 6B) largely overlap, although there is a subset of road plots that is clearly separated.

Table 2. Posterior densities of the ZIP model. Listed are the estimated means, estimated error (SD), 95\% credible interval (CI) and 50\%-89\% highest density intervals (HDI) for the population and group level effects, together with those of the smoothing term and the zero-inflation parameter $\left(z_{i}\right)$.

\begin{tabular}{c|c|c|c|c|c|c}
\hline Terms & Coefficient & Mean & SD & $\mathbf{9 5 \%}$ CI & $\mathbf{5 0 \%}$ HDI & $\mathbf{8 9 \%}$ HDI \\
\hline \multirow{4}{*}{$\begin{array}{c}\text { Population } \\
\text { level }\end{array}$} & Intercept & -1.10 & 0.92 & {$[-2.86-0.97]$} & {$[-1.54--0.63]$} & {$[-2.54-0.07]$} \\
\cline { 2 - 7 } & Intermediate plot & -0.60 & 0.22 & {$[-1.02--0.15]$} & {$[-0.72--0.43]$} & {$[-0.93--0.24]$} \\
\cline { 2 - 7 } & Interior plot & -1.05 & 0.27 & {$[-1.57-0.52]$} & {$[-1.22--0.86]$} & {$[-1.46--0.61]$} \\
\cline { 2 - 7 } & Elevation & -2.21 & 3.58 & {$[-10.01-4.40]$} & {$[-4.22-0.21]$} & {$[-8.12-3.38]$} \\
\hline Group level & Region/corridor & 0.65 & 0.44 & {$[0.15-1.91]$} & & \\
\hline Smoothing & Elevation & 11.32 & 6.83 & {$[1.42-26.86]$} & {$[4.96-12.59]$} & {$[0.81-20.26]$} \\
\hline Family specific & $z_{i}$ & 0.07 & 0.06 & {$[0.00-0.21]$} & & \\
\hline
\end{tabular}
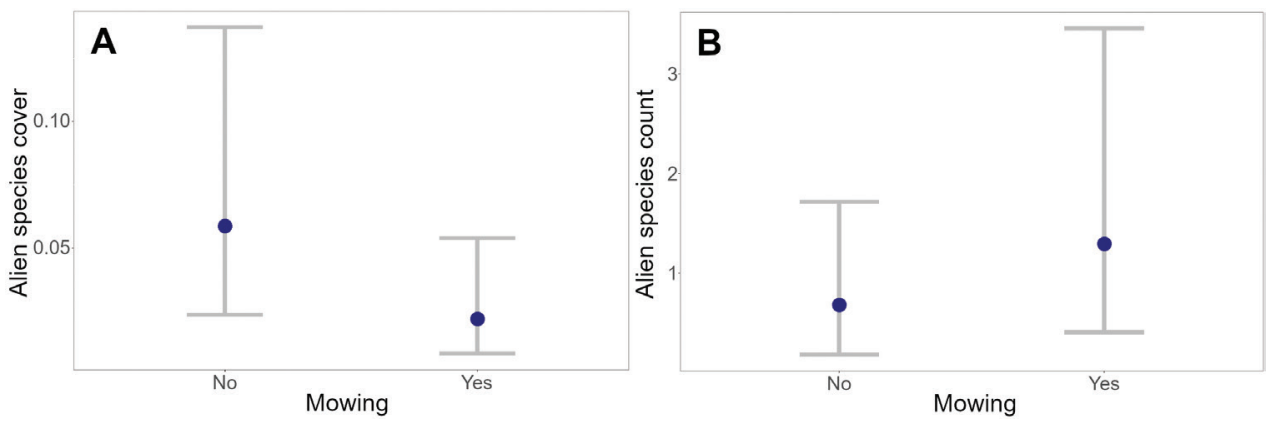

Figure 5. Posterior predictions of alien species cover and count for mown (Yes), and un-mown (No) plots. A the results of the zero-inflated beta (ZINB) model show a lower alien species cover in plots subject to mowing $\mathbf{B}$ contrastingly, the zero-inflated Poisson (ZIP) model indicates a higher alien species richness in mown plots. 
In the Lech region, again, river/road plots appear more distinct from the other plot types (Fig. 6C), and intermediate and interior plots have largely overlapping compositions. Our results suggest that communities along the river and the accompanying road in the Lech region are slightly more similar than those in the Isel region (Fig. 6D and paragraph below).

\section{Factors changing plot species composition}

The PERMANOVA test results (Table 3) for the Isel region show that the occurrence of alien species has a significant effect on plot species composition. The same applies to elevation and plot type. The betadisper test implies that there are heterogenous variances among plot types $(F=6.76, p=0.002)$ and the river and $\operatorname{road}(F=4.63, p=0.033)$. This means that the significant effect of plot type can be explained by a difference in species composition across plot types and possibly the difference of in-group dispersion between the plot types. The Holm-Bonferroni corrected pairwise test results (Table 3)
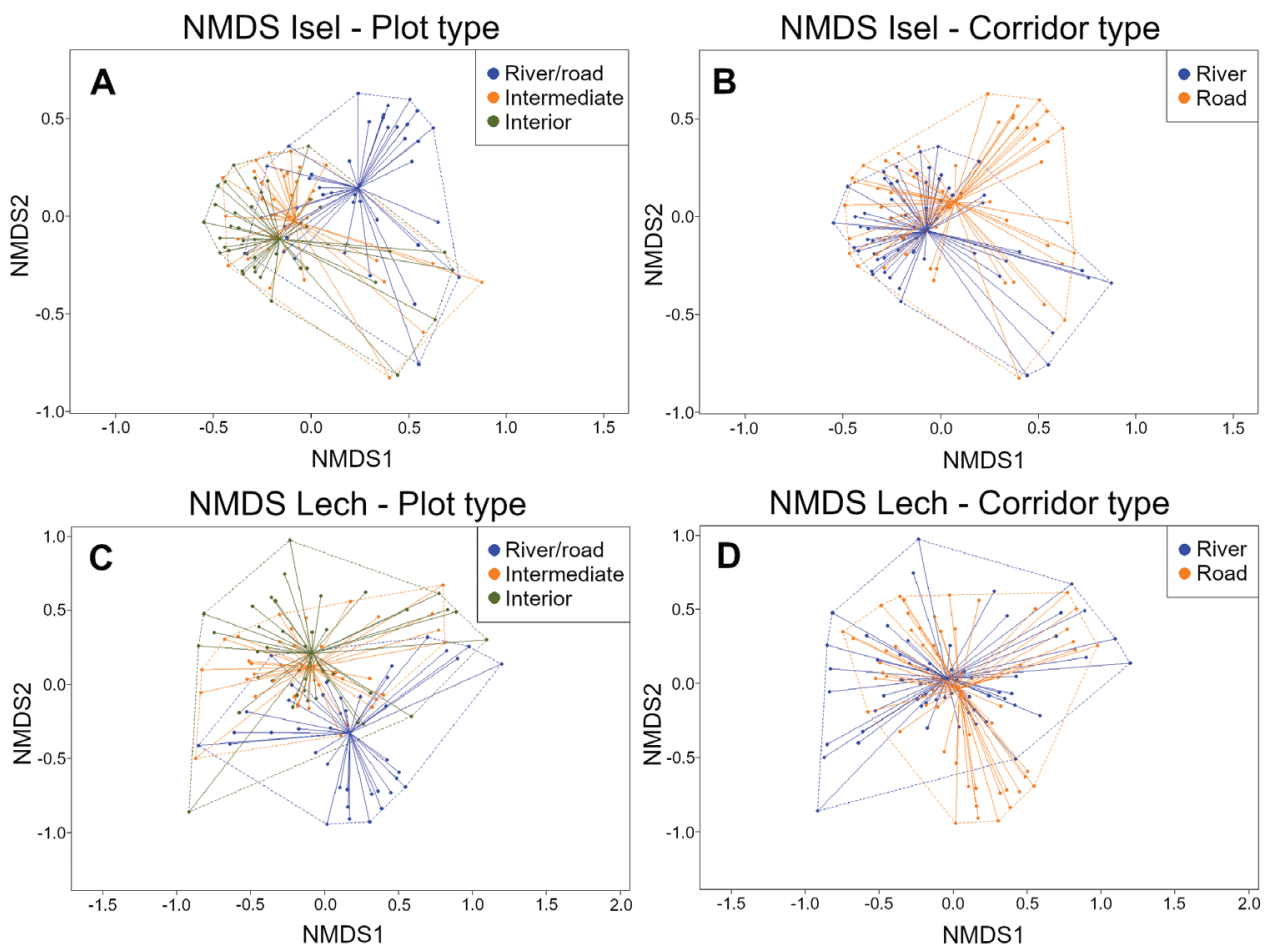

Figure 6. NMDS based on Bray-Curtis dissimilarities for the Isel and the Lech region. Illustrated are the species compositions in the Isel region predicted through the three different plot types $(\mathbf{A})$ and two corridor types (B), plus the species compositions according to plot type $(\mathbf{C})$ and corridor type $(\mathbf{D})$ in the Lech region. 
show that directly adjacent river/road plots differ from both intermediate and interior plots in species composition, while there is no difference between the latter two. Species composition of transects along the river and the road are significantly different.

The cover of alien species in the Lech region also has a significant effect on plot species composition, as does elevation and plot type (Table 4). The exception between the two regions is that the interaction between elevation and alien species cover for the Lech region is significant as well. The variances of the different plot types display heterogeneity $(F=6.85, p=0.002)$. Contrastingly, those between the river and road

Table 3. PERMANOVA test results $(\mathrm{n}=9999)$ based on Bray-Curtis dissimilarities for the Isel region. Shown are the effects of elevation, plot type, woody-herbaceous ratio, and alien species cover on plot species community. In addition, a pairwise comparison between the levels of plot type and corridor type is displayed. The unadjusted $p$-value is listed next to the $p$-value after Holm-Bonferroni correction.

\begin{tabular}{l|c|c|c|c}
\hline \multicolumn{1}{c|}{ Source } & DF & $\boldsymbol{F}$-statistic & $\boldsymbol{R}^{\mathbf{2}}$ & $\boldsymbol{p}$ \\
\hline Elevation & 1 & 10.05 & 0.07 & $<0.001$ \\
\hline Plot type & 2 & 5.83 & 0.08 & $<0.001$ \\
\hline Woody-herbaceous ratio & 1 & 10.32 & 0.07 & $<0.001$ \\
\hline Alien species cover & 1 & 3.34 & 0.02 & $<0.001$ \\
\hline Elevation x alien species cover & 1 & 1.19 & 0.01 & 0.255 \\
\hline Residuals & 113 & & 0.76 & \\
\hline Total Pairwise tests & 119 & & 1.00 & \\
\hline & DF & $\boldsymbol{F}$-statistic & $\boldsymbol{R}^{2}$ & $\boldsymbol{p} / \boldsymbol{p}_{\text {(adjusted) }}$ \\
\hline River/road vs. intermediate & 1 & 5.39 & 0.07 & $0.001 / 0.003$ \\
\hline River/road vs. interior & 1 & 7.98 & 0.09 & $0.001 / 0.003$ \\
\hline Intermediate vs. interior & 1 & 0.79 & 0.01 & $0.687 / 0.687$ \\
\hline River vs. road & 1 & 4.15 & 0.03 & $0.001 / 0.001$ \\
\hline
\end{tabular}

Table 4. PERMANOVA test results $(\mathrm{n}=9999)$ based on Bray-Curtis dissimilarities for the Lech region. Shown are the effects of elevation, plot type, woody-herbaceous ratio, and alien species cover on plot species community. In addition, a pairwise comparison between the levels of plot type and corridor type is displayed. The unadjusted $p$-value is listed next to the $p$-value after Holm-Bonferroni correction.

\begin{tabular}{l|c|c|c|c}
\hline \multicolumn{1}{c|}{ Source } & DF & $\boldsymbol{F}$-statistic & $\boldsymbol{R}^{\mathbf{2}}$ & $\boldsymbol{p}$ \\
\hline Elevation & 1 & 12.42 & 0.08 & $<0.001$ \\
\hline Plot type & 2 & 4.33 & 0.06 & $<0.001$ \\
\hline Woody-herbaceous ratio & 1 & 8.90 & 0.06 & $<0.001$ \\
\hline Alien species cover & 1 & 2.69 & 0.02 & $<0.001$ \\
\hline Elevation x alien species cover & 1 & 1.80 & 0.01 & 0.022 \\
\hline Residuals & 113 & & 0.77 & \\
\hline Total & 119 & & 1.00 & \\
\hline & DF & $\boldsymbol{F}$-statistic & $\boldsymbol{R}^{2}$ & $\boldsymbol{p} / \boldsymbol{p}_{\text {(adjusted) }}$ \\
\hline River/road vs. intermediate & 1 & 4.74 & 0.06 & $0.001 / 0.003$ \\
\hline River/road vs. interior & 1 & 5.16 & 0.06 & $0.001 / 0.003$ \\
\hline Intermediate vs. interior & 1 & 0.58 & 0.01 & $0.904 / 0.904$ \\
\hline River vs. road & 1 & 4.26 & 0.04 & $0.001 / 0.001$ \\
\hline
\end{tabular}


do not $(F=1.81, p=0.182)$. The Bonferroni-corrected pairwise test results show that river/road plots differ significantly from intermediate and interior plots, while the latter two do not differ from one another (Table 4). Comparing river and road transects shows a significant difference.

\section{Discussion}

We found a strong decrease in alien species richness with elevation along rivers and roads, and in both study regions. Our findings along roads are in line with previous studies on the functionality of roads as corridors for mountain invasions (Alexander et al. 2016; Seipel et al. 2016). The distribution pattern of alien plant species along the rivers also resembles findings in other regions (Barni et al. 2012). Further, our results for rivers show that invasion patterns are similar to those encountered along mountain roads in the study area, and that habitats at high elevations are less invaded than lowand mid-elevation habitats. This decrease of alien species richness and elevation can be attributed to a decrease in temperature, as well as a decrease in human influence (Marini et al. 2009; Marini et al. 2012; Dainese et al. 2014) and is supported when comparing the lower lying Isel valley and the Lech valley in our study. However, given that we only investigated two valleys, more research is needed to establish that the observed pattern along rivers, in relation to their accompanying roads, can be generalized.

\section{The role of rivers and roads in the spread of alien species}

The higher alien plant species richness observed in plots directly located parallel to roadsides and riverbanks, as opposed to plots located further away from these networks, strongly highlights their eminent role for alien species spread in mountain valleys (Seipel et al. 2012). While it has been known that roads and rivers are important linear structures for the spread of alien species in lowland areas of central and northern Europe (Pyšek and Prach 1994; Follak et al. 2018), we show here that they also produce similar patterns for the distribution of alien plants in the Austrian Alps. We found that alien plants spread further upward along roads compared to rivers, likely because passive dispersal of species along roads is bidirectional (e.g. upwards and downwards by cars) but predominantly unidirectional along rivers (e.g. downstream drift; Wang et al. 2011; Alexander et al. 2016). Microclimatic conditions of roadsides might be more favorable with higher temperatures along roads compared to the surrounding landscape (Forman et al. 2003).

Remarkably, we found that the contribution of roads and rivers to the spread of alien plants is complementary, as different alien plants are spreading along each of these corridors. This reflects differences in disturbance and habitat characteristics along rivers and roads. Riverine habitats are subject to substantial, mainly natural, levels of disturbance caused by hydro-morphological dynamics that create ample opportunities for the spread of alien plant species (Pyšek and Prach 1994; Aronson et al. 2017). 
Roadside habitats on the other hand are shaped by extensive anthropogenic habitat modifications and disturbances associated with the maintenance of road infrastructures. They are characterized by warm microclimate, frequent mowing, and often saline soil conditions resulting from the application of de-icing salt in winter that allows for the spread of salt-tolerant species (Pavol et al. 2013; Lázaro-Lobo and Ervin 2019). A process that is clearly reflected by the abundance of the facultative halophyte Puccinellia distans, which was observed in $60 \%$ of the road plots in the Lech valley and $65 \%$ of the road plots in the Isel valley.

Matricaria discoidea was commonly found along roads but absent on riverbanks, and Erigeron canadensis and Galinsoga ciliata were almost solely present next to roads. These species share a strong resistance to trampling caused by traffic, as frequently seen on roadsides (Carni and Mucina 1998). While this feature is lacking on riverbanks, these zones do have their own unique characteristics that promote the settlement of another subset of alien plant species. For example, their wet and open habitat, without mowing, gives species such as Cornus sericea, Fallopia japonica, and Impatiens glandulifera the ability to form thick stances that can remain unnoticed by conservationists (Pyšek and Prach 1994). Thus, while the specific types of disturbance regimes differ strongly between habitats associated with rivers and roads, they both facilitate the spread of alien plant species.

\section{Effects of roadside management}

Roadside management (i.e. mowing) increased alien species richness and decreased alien species cover. This might be explained by the selective pressure that mowing imposes on plants. Especially late-flowering annual species such as Impatiens glandulifera and Erigeron annuus fail to propagate when mown before seed development (Regan et al. 2006). While in our case roadside mowing was likely intended for road safety and not alien species management, in other regions it has proven to be an effective management method for limiting the spread of alien plants when the timing is correct (Milakovic et al. 2014). This way alien plant species dispersal along roads by passing vehicular traffic can be substantially reduced (von der Lippe et al. 2013). At the same time, the mowing machinery itself can act as a vector for seed dispersal across regions, a process that needs to be accounted for in management strategies (Vitalos and Karrer 2009). In addition, many short-lived alien species occurring at roadsides (e.g. Erigeron canadensis, Matricaria discoidea, Galinsoga spp.) respond adaptively to frequent mowing by developing dwarf individuals that are able to set fruits at branches growing below cutting height of conventional roadside mowing machines (Milakovic et al. 2014). Future management options in the study systems should include a rigorous monitoring of alien plant species along roadsides and their response to mowing activity. Based on these monitoring efforts, targeted measures for a mowing regime that accounts for both road safety and alien species management should be developed, including conservation scientists in the process. These measures should be consistently re-evaluated and if necessary adapted to changing conditions and potential new alien species. 


\section{Effects of alien species on resident vegetation}

The decreasing effect of alien species on community composition with increasing elevation likely results from lower temperatures in high-elevation plots along roads and rivers that limits alien species performance and thus spread. For example, in Switzerland, Erigeron annuus is found to have a higher winter seedling mortality at elevations above $1000 \mathrm{~m}$ (Trtikova et al. 2010). Additionally, less propagule pressure and roadside disturbance due to lower traffic intensity likely reduces alien species effects (Chytrý et al. 2008; Dullinger et al. 2009; Lembrechts et al. 2016b). In the future, however, it is possible that the effect of alien plants at higher elevations will increase as more species are projected to establish in these habitats (Pyšek et al. 2012), and more alien plants will spread into surrounding mountain vegetation (McDougall et al. 2018). The expenditure of agricultural lands in the Austrian Alps is one of the factors that can advance the introduction and distribution of alien plant species (Krausmann et al. 2003). Domesticated animals can function as a vector for alien plant seeds, by both endozoochory (ingestion) and epizoochory (carrying in fur) (Vavra et al. 2007). Similarly, tourism is an important driver of alien species invasions, as tourists can spread seeds by means of clothes, vehicles, etc. (Anderson et al. 2015). Further, the horticulture embodied by mountain villages also forms a pathway for high elevation introductions of alien plants (Kueffer et al. 2013). In our study regions, alien species appear to spread more strongly into habitats when there was some form of disturbance (i.e. logging) present, but more research and data is necessary to analyze such a relationship.

\section{Conclusions}

This study is, to our knowledge, the only one to date comparing alien species distribution across two highly different potential invasion corridors - a natural one (rivers) and a man-made one (roads) - in mountain regions. While both contribute to alien species' spread in mountain valleys, they do so for different alien species, and most species are confined to plots directly adjacent to roadsides and riverbanks. The alien plant species occurring in plots along rivers are distinct from the ones along roads and had lower upper limits than the respective sites along roads. Increased human activity and rising temperatures in alpine valleys are likely to reduce environmental constraints currently in place for alien plant species. The geographical isolation of mountain valleys and their early stage of alien plant invasion provide opportunities for conservation efforts. Nonetheless, further investigation into the spreading patterns of alien plants along alpine rivers is key to effective control.

\section{Acknowledgements}

BL and FE acknowledge funding by the Austrian Science Fund (FWF; grant no: I 2086-B29). Additional funding was provided by the Leiden University Fund (L17074). 
Dr. Leni Duistermaat provided valuable suggestions for the fieldwork and comments on earlier versions of the manuscript. We particularly thank Dr. Sylvia Haider for input on the MIREN sampling protocol. We would also like to thank Dr. Johannes Wessely for fruitful discussions on the statistical methods. We appreciate the constructive comments of the Editor in Chief, Ingolf Kühn, and of two anonymous reviewers. The authors declare that there are no competing interests.

\section{References}

Aikio S, Duncan RP, Hulme PE (2010) Lag-phases in alien plant invasions: separating the facts from the artefacts. Oikos 119(2): 370-378. https://doi.org/10.1111/j.16000706.2009.17963.x

Alexander JM, Lembrechts JJ, Cavieres LA, Daehler C, Haider S, Kueffer C (2016) Plant invasions into mountains and alpine ecosystems: current status and future challenges. Alpine Botany 126: 89-103. https://doi.org/10.1007/s00035-016-0172-8

Alexander JM, Burgess TI, Chalmandrier L, Essl F, Haider S, Kueffer C, Lenoir J, McDougall K, Milbau A, Nuñez MA, Pauchard A, Rabitsch W, Rew LJ, Sanders S, Pellissier L (2018) Lags in the response of mountain plant communities to climate change. Global Change Biology 24(2): 563-574. https://doi.org/10.1111/gcb.13976

Amano T, Coverdale R, Peh KSH (2016) The importance of globalization in driving the establishment of alien species in Europe. Ecography 39(11): 1118-1128. https://doi. org/10.1111/ecog.01893

Anderson MJ (2008) A new method for non-parametric multivariate analysis of variance. Austral Ecology 26(1): 32-46. https://doi.org/10.1046/j.1442-9993.2001.01070.x

Anderson LG, Rocliffe S, Haddaway NR, Dunn AM (2015) The role of tourism and recreation in the spread of non-native species: A systematic review and meta-analysis. PLoS ONE 10(10): e0140833. https://doi.org/10.1371/journal.pone.0140833

Arbizu PM (2019) PairwiseAdonis: Pairwise multilevel comparison using adonis. R package version 0.3 .

Aronson MFJ, Patel MV, O’Neill KM, Ehrenfeld JG (2017) Urban riparian systems function as corridors for both native and invasive plant species. Biological Invasions 19: 3645-3657. https://doi.org/10.1007/s10530-017-1583-1

ASFINAG (2019) Autobahnen- und Schnellstraßen-Finanzierungs-Aktiengesellschaft.

Barni E, Bacaro G, Falzoi S, Spanna F, Siniscalco C (2012) Establishing climatic constraints shaping the distribution of alien plant species along the elevation gradient in the Alps. Plant Ecology 213(5): 757-767. https://doi.org/10.1007/s11258-012-0039-z

Becker T, Dietz H, Billeter R, Buschmann H, Edwards PJ (2005) Altitudinal distribution of alien plant species in the Swiss Alps. Perspectives in Plant Ecology Evolution and Systematics 7(3): 173-183. https://doi.org/10.1016/j.ppees.2005.09.006

Bellard C, Jeschke JM, Leroy B, Mace GM (2018) Insights from modeling studies on how climate change affects invasive alien species geography. Ecology and Evolution 8(11): 5688-5700. https://doi.org/10.1002/ece3.4098 
Bray JR, Curtis JT (1957) An ordination of upland forest communities of southern Wisconsin. Ecological Monographs 27(4): 325-349. https://doi.org/10.2307/1942268

Bürkner PC (2018) Advanced Bayesian Multilevel Modeling with the R Package brms. The R Journal 10(1): 395-411. https://doi.org/10.32614/RJ-2018-017

Bürkner PC (2020) Brms: An R Package for Bayesian Multilevel Models using Stan. R package version 2.11.0.

Caley P, Groves RH, Barker R (2007) Estimating the invasion success of introduced plants. Diversity and Distributions 14(2): 196-203. https://doi.org/10.1111/j.1472-4642.2007.00440.x

Carboni M, Guéguen M, Barros C, Georges D, Boulangeat I, Douzet R, Dullinger S, Klonner G, van Kleunen M, Essl F, Bossdorf O, Haeuser E, Talluto MV, Moser D, Block S, Conti L, Dullinger I, Münkemüller T, Thuiller W (2018) Simulating plant invasion dynamics in mountain ecosystems under global change scenarios. Global Change Biology 24(1): 289-302. https://doi.org/10.1111/gcb.13879

Carni A, Mucina L (1998) Vegetation of trampled soil dominated by C4 plants in Europe. Journal of Vegetation Science 9(1): 45-56. https://doi.org/10.2307/3237222

Chytrý M, Jarošík V, Pyšek P, Hájek O, Knollová I, Tichý L, Danihelka J (2008) Separating habitat invasibility by alien plant form the actual level of invasion. Ecology 89(6): 1541-1553. https://doi.org/10.1890/07-0682.1

Dainese M, Kühn I, Bragazza L (2014) Alien plant species distribution in the European Alps: influence of species' climatic requirements. Biological Invasions 16: 815-831. https://doi. org/10.1007/s10530-013-0540-x

Diez JM, D’Antonio CM, Dukes JS, Grosholz ED, Olden JD, Sorte CJB, Blumenthal DM, Bradley BA, Early R, Ibáñez I, Jones SJ, Lawler JJ, Miller LP (2012) Will extreme climatic events facilitate biological invasions? Frontiers in Ecology and the Environment 10(5): 249-257. https://doi.org/10.1890/110137

Dullinger S, Kleinbauer I, Peterseil J, Smolik M, Essl F (2009) Niche based distribution modeling of an invasive alien plant: effects of population status, propagule pressure and invasion history. Biological Invasions 11: 2401-2414. https://doi.org/10.1007/s10530-009-9424-5

Ellenberg H (1996) Vegetation Mitteleuropas mit den Alpen: in ökologischer, dynamischer und historischer Sicht. UTB (Stuttgart): 1-1095.

ESRI (2014) ArcGIS Desktop: Release 10.2.2. Redlands, CA: Environmental Systems Research Institute.

Essl F, Rabitsch W (2002) Neobiota in Österreich. Wien: Umweltbundesamt.

Fischer MA, Oswald K, Adler W (2008) Exkursionsflora für Österreich, Liechtenstein und Südtirol. Biologiezentrum der Oberösterreichischen Landesmuseen (Linz).

Follak S, Eberius M, Essl F, Fürdös A, Sedlacek N, Trognitz F (2018) Invasive alien plants along roadsides in Europe. EPPO Bulletin 48(2): 256-265. https://doi.org/10.1111/epp.12465

Forman RTT, Sperling D, Bissonette JA, Clevenger AP, Cutshall CD, Dale VH, Fahrig L, France R, Goldman CR, Heanue K, Jones JA, Swanson FJ, Turrentine T, Winter TC (2003) Road Ecology: Science and Solutions. Island Press (Washington, DC): 75-111.

Goral F, Schellenberg J (2018) goeveg: Functions for community data and ordinations. R package version 0.4.2. 
Greenwood P, Baumann P, Pulley S, Kuhn NJ (2018) The invasive alien plant, Impatiens glandulifera (Himalayan Balsam), and increased soil erosion: causation or association? Case studies from a river system in Switzerland and the UK. Journal of Soils and Sediments 18: 3463-3477. https://doi.org/10.1007/s11368-018-2041-0

Haider S, Kueffer C, Bruelheide H, Seipel T, Alexander JM, Rew LJ, Arévalo JR, Cavieres LA, McDougall KL, Milbau A, Naylor BJ, Speziale K, Pauchard A (2018) Mountain roads and non-native species modify patterns of plant diversity. Global Ecology and Biogeography 27(6): 667-678. https://doi.org/10.1111/geb.12727

Hansen MJ, Clevenger AP (2005) The influence of disturbance and habitat on the presence of non-native plant species along transport corridors. Biological Conservation 125(2): 249-259. https://doi.org/10.1016/j.biocon.2005.03.024

Harrison XA, Donaldson L, Correa-Cano ME, Evans J, Fisher DN, Goodwin CED, Robinson BS, Hodgson DJ, Inger R (2018) A brief introduction to mixed effects modelling and multi-model inference in ecology. PeerJ 6: e4794. https://doi.org/10.7717/peerj.4794

Hejda M, Pyšek P, Jarošík V (2009) Impact of invasive plants on the species richness, diversity and composition of invaded communities. Ecology 97(3): 393-403. https://doi. org/10.1111/j.1365-2745.2009.01480.x

Holm S (1979) A Simple Sequentially Rejective Multiple Test Procedure. Scandinavian Journal of Statistics 6(2): 65-70.

Hulme PE (2009) Trade, transport and trouble: managing invasive species pathways in an era of globalization. Journal of Applied Ecology 46(1): 10-18. https://doi.org/10.1111/j.13652664.2008.01600.x

Jantunen J, Saarinen K, Valtonen A, Saarnio S (2007) Flowering and seed production success along roads with different mowing regimes. Applied Vegetation Science 10(2): 285-292. https://doi.org/10.1111/j.1654-109X.2007.tb00528.x

Kalusová V, Chytrý M, Kartesz JT, Nishino M, Pyšek P (2013) Where do they come from and where do they go? European natural habitats as donors of invasive alien plants globally. Diversity and Distributions 19(2): 199-214. https://doi.org/10.1111/ddi.12008

Kettenring KM, Adams CR (2011) Lessons learned from invasive plant control experiments: a systematic review and meta-analysis. Journal of Applied Ecology 48(4): 970-979. https:// doi.org/10.1111/j.1365-2664.2011.01979.x

Krausmann F, Haberl H, Schulz NB, Erb KH, Darge E, Gaube V (2003) Land-use change and socioeconomic metabolism in Austria, part I: Driving forces of land-use change 1950-1995. Land Use Policy 20(1): 1-20. https://doi.org/10.1016/S0264-8377(02)00048-0

Kueffer C (2017) Plant invasions in the Anthropocene. Science 358(6364): 724-725. https:// doi.org/10.1126/science.aao6371

Kueffer C, McDougall K, Alexander J, Daehler C, Edwards P, Haider S, Milbau A, Parks C, Pauchard A, Reshi ZA, Rew LJ, Schroder M, Seipel T (2013) Plant invasions into mountain protected areas: assessment, prevention and control at multiple spatial scales. In: Foxcroft L, Pyšek P, Richardson D, Genovesi P (Eds). Plant invasions in protected areas. Invading Nature - Springer Series in Invasion Ecology. Springer (Dordrecht): 89-113. https://doi. org/10.1007/978-94-007-7750-7_6 
Lambert D (2012) Zero-inflated poisson regression, with an application to defects in manufacturing. Technometrics 34(1): 1-14. https://doi.org/10.2307/1269547

Lázaro-Lobo A, Ervin GN (2019) A global examination on the differential impacts of roadsides on native vs. exotica and weedy plant species. Global Ecology and Elevation 17: e00555. https://doi.org/10.1016/j.gecco.2019.e00555

Lembrechts JJ, Pauchard A, Lenoir J, Nuñez MA, Geron C, Ven A, Bravo-Monasterio P, Teneb E, Nijs I, Milbau A (2016a) Disturbance is the key to plant invasions in cold environments. PNAS 113(49): 14061-14066. https://doi.org/10.1073/pnas.1608980113

Lembrechts JJ, Alexander JM, Cavieres LA, Haider S, Lenoir J, Kueffer C, McDougall K, Naylor BJ, Nuñez MA, Pauchard A, Rew LJ, Nijs I, Milbau A (2016b) Mountain roads shift native and non-native plant species ranges. Ecography 40(3): 353-364. https://doi. org/10.1111/ecog.02200

Lemke A, Kowarik I, von der Lippe M (2019) How traffic facilitates population expansion of invasive species along roads: The case of common ragweed in Germany. Journal of Applied Ecology 56(2): 413-422. https://doi.org/10.1111/1365-2664.13287

Lenoir J, Gégout JC, Marquet PA, de Ruffray P, Brisse H (2008) A significant upward shift in plant species optimum elevation during the $20^{\text {th }}$ century. Science $320(5884): 1768-1771$. https://doi.org/10.1126/science.1156831

Marini L, Gaston KJ, Prosser F, Hulme PE (2009) Contrasting response of native and alien plant species richness to environmental energy and human impact along alpine elevation gradients. Global Ecology and Biogeography 18(6): 652-661. https://doi.org/10.1111/ j.1466-8238.2009.00484.x

Marini L, Battisti A, Bona E, Federici G, Martini F, Pautasso M, Hulme PE (2012) Alien and plant life-forms respond differently to human and climate pressures. Global Ecology Biogeography 21: 534-544. https://doi.org/10.1111/j.1466-8238.2011.00702.x

McDougall KL, Lembrechts J, Rew LJ, Haider S, Cavieres LA, Kueffer C, Milbau A, Naylor BJ, Nuñez MA, Pauchard A, Seipel T, Speziale KL, Wright GT, Alexander JM (2018) Running off the road: roadside non-native plants invading mountain vegetation. Biological Invasions 20: 3461-3473. https://doi.org/10.1007/s10530-018-1787-z

Milakovic I, Fiedler K, Karrer G (2014) Management of roadside populations of invasive Ambrosia artemisiifolia by mowing. Weed research 54(3): 256-264. https://doi.org/10.1111/ wre. 12074

Montgomery DR (2002) Valley formation by fluvial and glacial erosion. Geology 30(11): 1047-1050. https://doi.org/10.1130/0091-7613(2002)030\%3C1047:VFBFAG\%3E2.0. $\mathrm{CO} ; 2$

Müller N, Bürger A (1990) Flußbettmorphologie und Auenvegetation des Lech im Bereich der Forchacher Wildflußlandschaft (Oberes Lechtal, Tirol). Jahrbuch des Vereins zum Schutz der Bergwelt 55: 123-154.

Naiman RJ, Décamps H (1997) The ecology of interfaces: riparian zones. Annual Review of Ecology and Systematics 28: 621-658. https://doi.org/10.1146/annurev.ecolsys.28.1.621

Oksanen J, Blanchet FG, Friendly M, Kindt R, Legendre P, McGlinn D, Minchin PR, O'Hara RB, Simpson GL, Solymos P, Stevens MHH, Szoecs E, Wagner H (2019) Vegan: Community Ecology Package. R package version 2.5-6. 
Opitz T, Tramini P, Molinari N (2013) Spline regression for zero-inflated models. Journal of Biostatistics 9: 1-17.

Osawa T, Mitsuhashi H, Niwa H (2013) Many alien invasive plants disperse against the direction of stream flow in riparian areas. Ecological Complexity 15: 26-32. https://doi. org/10.1016/j.ecocom.2013.01.009

Ospina R, Ferrari SLP (2012) A general class of zero-or-one inflated beta regression models. Computational Statistics \& Data Analysis 56(6): 1609-1623. https://doi.org/10.1016/j. csda.2011.10.005

Pattison Z, Minderman J, Boon PJ, Willby N (2017) Twenty years of change in riverside vegetation: what role have invasive alien plants played? Applied Vegetation Science 20(3): 422-434. https://doi.org/10.1111/avsc. 12297

Pauchard A, Kueffer C, Dietz H, Daehler CC, Alexander J, Edwards PJ, Arévalo JR, Cavieres LA, Guisan A, Haider S, Jakobs G, McDougall K, Millar CI, Naylor BJ, Parks CG, Rew LJ, Seipel T (2009) Ain't no mountain high enough: plant invasions reaching new elevations. Frontiers in Ecology and the Environment 7(9): 479-486. https://doi. org/10.1890/080072

Pauchard A, Milbau A, Albihn A, Alexander J, Burgess T, Daehler C, Englund G, Essl F, Evengård B, Greenwood GB, Haider S, Lenoir J, McDougall K, Muths E, Nuñez MA, Olofsson J, Pellisier L, Rabitsch W, Rew LJ, Robertson M, Sanders N, Kueffer C (2016) Non-native and native organisms moving into high elevation and high latitude ecosystems in an era of climate change: new challenges for ecology and conservation. Biological Invasions 18: 345-353. https://doi.org/10.1007/s10530-015-1025-x

Pavol E, Sopotlieva D, Dítě D, Hájkova P, Apostolova I, Senko D, Melečková Z, Hájek M (2013) Vegetation diversity of salt-rich grasslands in Southeast Europe. Applied Vegetation Science 16(3): 521-537. https://doi.org/10.1111/avsc.12017

Petitpierre B, McDougall K, Seipel T, Broennimann O, Guisan A, Kueffer C (2015) Will climate change increase the risk of plant invasions into mountains? Ecological Applications 26(2): 530-544. https://doi.org/10.1890/14-1871

Pyšek P, Prach K (1994) How important are rivers for supporting plant invasions? De Waal LC, Child LE, Wade PM, Brock JH (Eds) In: Ecology and management of invasive riverside plants. Wiley (Chichester): 19-26.

Pyšek P, Jarošik V, Hulme PE, Pergl J, Hejda M, Schaffner U, Vilà M (2012) A global assessment of invasive plant impacts on resident species, communities and ecosystems: the interaction of impact measures, invading species' traits and environment. Global Change Biology 18(5): 1725-1737. https://doi.org/10.1111/j.1365-2486.2011.02636.x

Rauschert ESJ, Mortensen DA, Bloser SM (2017) Human-mediated dispersal via rural road maintenance can move invasive propagules. Biological invasions 19: 2047-2058. https:// doi.org/10.1007/s10530-017-1416-2

R Development Core Team (2019) R: A language and environment for statistical computing. R Foundation for Statistical Computing, Vienna, Austria.

Regan TJ, McCarthy MA, Baxter PWJ, Panetta FD, Possingham HP (2006) Optimal eradication: when to stop looking for an invasive plant. Ecology Letters 9(7): 759-766. https:// doi.org/10.1111/j.1461-0248.2006.00920.x 
Richardson DM, Holmes PM, Esler KJ, Galatowitsch SM, Stromberg JC, Kirkman SP, Pyšek P, Hobbs RJ (2007) Riparian vegetation: degradation, alien plant invasions, and restoration prospects. Diversity and Distributions 13(1): 126-139. https://doi.org/10.1111/j.13669516.2006.00314.x

Rouget M, Robertson MP, Wilson JRU, Hui C, Essl F, Renteria JL, Richardson DM (2016) Invasion debt - quantifying future biological invasions. Diversity and Distributions 22(4): 445-456. https://doi.org/10.1111/ddi.12408

Schiffleithner V, Essl F (2016) Is it worth the effort? Spread and management success of invasive alien plant species in a Central European National Park. NeoBiota 31: 43-61. https://doi. org/10.3897/neobiota.31.8071

Seebens H, Essl F, Dawson W, Fuentes N, Moser D, Pergl J, Pyšek P, van Kleunen M, Weber E, Winter M, Blasius B (2015) Global trade will accelerate plant invasions in emerging economies under climate change. Global Change Biology 21(11): 4128-4140. https://doi. org/10.1111/gcb.13021

Seebens H, Blackburn TM, Dyer EE, Genovesi P, Hulme PE, Jeschke JM, Pagad S, Pyšek P, Winter M, Arianoutsou M, Bacher S, Blasius B, Brundu G, Capinha C, Celesti-Grapow L, Dawson W, Dullinger S, Fuentes N, Jäger H, Kartesz J, Kenis M, Kreft H, Kühn I, Lenzner B, Liebhold A, Mosena A, Moser D, Nishino M, Pearman D, Pergl J, Rabitsch W, RojasSandoval J, Roques A, Rorke S, Rossinelli S, Roy HE, Scalera R, Schindler S, Štajerová K, Tokarska-Guzik B, van Kleunen M, Walker K, Weigelt P, Yamanaka T, Essl F (2017) No saturation in the accumulation of alien species worldwide. Nature Communications 8: 14435. https://doi.org/10.1038/ncomms14435

Seipel T, Alexander JM, Edwards PJ, Kueffer C (2016) Range limits and population dynamics of non-native plants spreading along elevation gradients. Perspectives in Plant Ecology, Evolution and Systematics 20: 46-55. https://doi.org/10.1016/j.ppees.2016.04.001

Seipel T, Kueffer C, Rew L, Daehler C, Pauchard A, Naylor BJ, Alexander JM, Edwards PJ, Parks CG, Arevalo JR, Cavieres LA, Dietz H, Jakobs G, McDougall K, Otto R, Walsh N (2012) Processes at multiple scales affect richness and similarity of non-native plant species in mountains around the world. Global Ecology and Biogeography 21(2): 236-246. https://doi.org/10.1111/j.1466-8238.2011.00664.x

Siniscalco C, Barni E, Bacaro G (2011) Non-native species distribution along the elevation gradient in the western Italian Alps. Plant Biosystems 145(1): 150-158. https://doi.org/10 $.1080 / 11263504.2010 .540786$

Song U, Son D, Kang C, Lee EJ, Lee K, Park JS (2018) Mowing: A cause of invasion, but also a potential solution for management of the invasive, alien plant species Erigeron annuus (L.) Pers. Journal of Environmental Management 223: 530-536. https://doi.org/10.1016/j. jenvman.2018.06.057

Stotz GC, Pec GJ, Cahill JF (2016) Is biotic resistance to invaders dependent upon local environmental conditions or primary productivity? A meta-analysis. Basic and Applied Ecology 17(5): 377-387. https://doi.org/10.1016/j.baae.2016.04.001

Trtikova M, Edwards PJ, Güsewell S (2010) No adaptation to altitude in the invasive plant Erigeron annuus in the Swiss Alps. Ecography 33(3): 556-564. https://doi.org/10.1111/ j.1600-0587.2009.05708.x 
Van Kleunen M, Essl F, Pergl J, Brundu G, Carboni M, Dullinger S, Early R, González-Moreno P, Groom QJ, Hulme PE, Kueffer C, Kühn I, Máguas C, Maurel N, Novoa A, Parepa M, Pyšek P, Seebens H, Tanner R, Touza J, Verbrugge L, Weber E, Dawson W, Kreft H, Weigelt P, Winter M, Klonner G, Talluto MV, Dehnen-Schmutz K (2018) The changing role of ornamental horticulture in alien plant invasions. Biological Reviews 93(3): 1-60. https://doi.org/10.1111/brv.12402

Van Kleunen M, Dawson W, Essl F, Pergl J, Winter M, Weber E, Kreft H, Weigelt P, Kartesz J, Nishino M, Antonova LA, Barcelona JF, Cabezas FJ, Cárdenas D, Cárdenas-Toro J, Castaño N, Chacón E, Chatelain C, Ebel AL, Figueiredo E, Fuentes N, Groom QJ, Henderson L, Inderjit, Kupriyanov A, Masciadri S, Meerman J, Morozova O, Moser D, Nickrent DL, Patzelt A, Pelser PB, Baptiste MP, Poopath M, Schulze M, Seebens H, Shu W, Thomas J, Velayos M, Wieringa JJ, Pyšek P (2015) Global exchange and accumulation of non-native plants. Nature 525: 100-103. https://doi.org/10.1038/nature14910

Vavra M, Parks CG, Wisdom MJ (2007) Biodiversity, exotic plant species, and herbivory: The good, the bad, and the ungulate. Forest Ecology and Management 246(1): 66-72. https:// doi.org/10.1016/j.foreco.2007.03.051

Vitalos M, Karrer G (2009) Dispersal of Ambrosia artemisiifolia seeds along roads: the contribution of traffic and mowing machines. Pyšek P, Pergl J (Eds) In: Biological invasions: Towards a synthesis. NeoBiota 8: 53-60.

Von der Lippe M, Kowarik I (2007) Long-distance dispersal of plant by vehicles as a driver of plant invasions. Conservation Biology 21(4): 986-996. https://doi.org/10.1111/j.15231739.2007.00722.x

Von der Lippe M, Bullock JM, Kowarik I, Knopp T, Wichmann M (2013) Human-mediated dispersal of seeds by the airflow of vehicles. PLoS ONE 8(1): e52733. https://doi. org/10.1371/journal.pone.0052733

Walter J, Essl F, Englisch T, Kiehn M (2005) Neophytes in Austria: Habitat preferences and ecological effects. In Nentwig W (Ed) Biological Invasions - From Ecology to Control. Springer-verlag Heidelberg (Berlin): 13-25.

Walther G, Roques A, Hulme PE, Sykes MT, Pyšek P, Kühn I, Zobel M, Bacher S, Botta-Dukát Z, Bugmann H, Czúcz B, Dauber J, Hickler T, Jarošík V, Kenis M, Klotz S, Minchin D, Moora M, Nentwig W, Ott J, Panov VE, Reineking B, Robinet C, Semenchenko V, Solarz W, Thuiller W, Vilà M, Vohland K, Settele J (2009) Alien species in a warmer world: risks and opportunities. Trends in Ecology and Evolution 24(12): 686-693. https://doi. org/10.1016/j.tree.2009.06.008

Wang R, Wang JF, Qiu ZJ, Meng B, Wan FH, Wang YZ (2011) Multiple mechanisms underlie rapid expansion of an invasive alien plant. New Phytologist 191(3): 828-839. https://doi. org/10.1111/j.1469-8137.2011.03720.x

ZAMG (2019) Central Institute for Meteorology and Geodynamics (Vienna). 


\section{Supplementary material I}

\section{Plot information}

Authors: Tom Vorstenbosch, Franz Essl, Bernd Lenzner

Data type: Sampling site information

Copyright notice: This dataset is made available under the Open Database License (http://opendatacommons.org/licenses/odbl/1.0/). The Open Database License $(\mathrm{ODbL})$ is a license agreement intended to allow users to freely share, modify, and use this Dataset while maintaining this same freedom for others, provided that the original source and author(s) are credited.

Link: https://doi.org/10.3897/neobiota.63.55096.suppl1

\section{Supplementary material 2}

\section{Appendix 1-8}

Authors: Tom Vorstenbosch, Franz Essl, Bernd Lenzner

Data type: Additional methods information, Model evaluation, Model result tables Explanation note: Appendix 1. Roadside mowing line. Appendix 2. Visualization of cover estimation for plant individuals. Appendix 3A. Post-warmup iterations of the ZIP model. Appendix 3B. Posterior predictions vs. observed data. Appendix 3C. Posterior predictions vs. observed data. Appendix 3D. Posterior predictions of the zero-probability. Appendix 4A. Trace plots of post-warmup iterations for the ZINB model that estimates the effect of mowing. Appendix 4B. Posterior predictions vs. observed data. Appendix 4C. Posterior predictions of the zero-probability. Appendix 5A. Post-warmup iterations for the ZIP model that estimates the effect of mowing. Appendix 5B. Posterior predictions vs. observed data. Appendix 5C. Posterior predictions of the zero-probability. Appendix 6. Estimated intercepts for the levels of the grouping factors in the ZIP model. Appendix 7. ZINB model posterior densities for the effect of mowing on alien species cover. Appendix 8. ZIP model posterior densities for the effect of mowing on alien species count.

Copyright notice: This dataset is made available under the Open Database License (http://opendatacommons.org/licenses/odbl/1.0/). The Open Database License $(\mathrm{ODbL})$ is a license agreement intended to allow users to freely share, modify, and use this Dataset while maintaining this same freedom for others, provided that the original source and author(s) are credited.

Link: https://doi.org/10.3897/neobiota.63.55096.suppl2 